\title{
Effect of Foreign Direct Investments on Economic Growth in CEMAC Zone: Role of Human Capital
}

\author{
Steve Bertrand Mboko Ibara \\ Faculty of Economic Sciences, Marien Ngouabi University, Brazzaville, Congo \\ Email: stevemboko@yahoo.fr
}

How to cite this paper: Mboko Ibara, S. B. (2020). Effect of Foreign Direct Investments on Economic Growth in CEMAC Zone: Role of Human Capital. Modern Economy, 11, 2122-2144.

https://doi.org/10.4236/me.2020.1112140

Received: November 6, 2020

Accepted: December 28, 2020

Published: December 31, 2020

Copyright (อ 2020 by author(s) and Scientific Research Publishing Inc. This work is licensed under the Creative Commons Attribution International License (CC BY 4.0).

http://creativecommons.org/licenses/by/4.0/

\section{(c) (i) Open Access}

\begin{abstract}
The objective of this paper is to analyze the role played by human capital in the relationship of foreign direct investment (FDI) and economic growth in the Central African Economic and Monetary Community (CEMAC). To achieve the assigned goal, we use the generalized method of moments (GMM) in a dynamic panel system proposed by Blundell et al. (2012) on annual series of 50 by country (Cameroon, Congo, Gabon, CAR, and Chad) ${ }^{1}$ from 1970 to $2019^{2}$. Two major conclusions emerged from this research. The first is that human capital in the CEMAC zone contributes significantly to improving the FDI-economic growth relationship. The second conclusion is that human capital has a negative and very significant effect on economic growth, all other things being equal. This result corroborates the threshold effect estimates that have shown that the CEMAC zone has not yet reached a level of human capital, enabling one to take advantage of the economic benefits specific to the return on investment in education or through spillovers.
\end{abstract}

\section{Keywords}

Economic-Growth, FDI, Human-Capital, CEMAC, GMM

\section{Introduction}

In the economic literature, the importance given to human capital stems from the fact that states' economic trajectories have historically been accompanied by a generalized increase in the average level of education and an improvement in the health status of populations (Becker, 1964; Fraisse D’Olimpio, 2009; Goumr-

${ }^{1}$ Equatorial Guinea was not included due to the lack of sufficient data on the human capital index. ${ }^{2}$ Data from 2018 to 2019 are estimates based on a moving average. 
har, 2017). This concordance of facts has promoted economic thought since the 1980s, whereas many theoretical and empirical studies carried out since then have given rise to a new look at the processes of economic growth. This new economic thought, commonly called "theories of endogenous growth" thus helped to understand the mystery of the residue not explained by the increase in the quantities of factors of production (e.g., capital, labor) in the works of Solow (1956) or in those of Mankiw, Romer and Weil (1992). However, because of the consideration of technical progress as exogenous to the process of economic growth, the model of Mankiw et al. (1992) has received much criticism (Aghion \& Howitt, 1992; Benhabib \& Spiegel, 1994). As a result, the Barro and Sala-i-Martin (1992) research is a major contribution in the sense that it has elucidated the Solow residue.

Complementary theoretical models refocusing the role of human capital in economic growth have been proposed (Aghion \& Howitt 1992; Funke \& Strulik, 2000). These theories, by demonstrating that economic growth no longer depended on physical capital alone but also on the accumulation of human capital and technical progress, were at the origin of one of the major upheavals in economic thought (Gundlach, 1995). Moreover, extension of the analysis of the mechanisms involved has made it possible to consider many other channels of transmission of the effect of human capital on growth. Openings have thus been made to innovation, research and development (R\&D), and adaptation to new technologies (Romer, 1990; Aghion \& Howitt, 1992; Benhabib \& Spiegel, 1994). The latter suggests that, in an economy with technical progress, the level of human capital impacts long-term growth via the positive effects it has on the capacity for innovation, $R \& D$, and the speed of adaptation to new technologies, for which foreign direct investment (FDI) is one of the main transmission channels (Borensztein, De Gregorio, \& Lee, 1998; Xu, 2000).

FDI contributes directly and indirectly to the growth of an economy by improving knowledge and technological spillovers, improving the stock of human capital, and encouraging production and consumption (Feenstra \& Markusen, 1994; Blomström \& Kokko, 2003). One specification of developed countries is the availability of a workforce with a high level of human capital (Miyamoto, 2003). However, the question of whether human capital is the main engine of growth in the developing world remains a matter of controversy. Some developing countries have followed similar trends in human capital and economic growth. The distinction of these developing countries is that they appear to have achieved significant economic benefits by attracting FDI in host economies and have mobilized FDI inflows to achieve rapid economic growth (Miyamoto, 2003).

However, among the empirical studies conducted on the impact of FDI on economic growth in both developed and developing countries, there has been very little return to the effect of FDI on human capital, a key factor of economic growth (Miyamoto, 2003; Azam et al., 2015). Not all studies on the impact of FDI around the world have led to positive effects on economic growth. 
In the case of the Central African Economic and Monetary Community (CEMAC), the divergences in economic trajectories (i.e., observation of convergence criteria, difference in standard of living, and human capital) raise questions as to the real effectiveness of FDI on the area's economic growth. For example, according to World Bank (2019), between 1970 and 2017, Congo was the only country in the CEMAC zone where the increase in FDI (191 percent) and human capital (1.2 percent) went hand in hand with the increase in gross domestic product (GDP) per capita (1.2 percent). On the other hand, the CAR is a country in the area that has experienced the weakest improvement in human capital (0.77 percent on annual average). This, combined with a 56.6 percent drop in FDI over the period, makes CAR the only country with a negative annual average GDP per capita ( -0.96 percent). Cameroon, with the highest average annual variation in per capita GDP over the period (1.19 percent), contrasts with a stronger drop in FDI (-1369.6 percent $)^{3}$.

Thus, in light of that argued above, are we entitled to know what role human capital plays in the FDI-economic growth relationship in the CEMAC zone? The general objective of this research is to analyze the role of human capital in the FDI-economic growth relationship in the CEMAC zone. More specifically, it is a question of verifying whether, in CEMAC, the impact of FDI on economic growth is as strong as the high level of human capital. It is assumed that, in the CEMAC zone, human capital plays a positive and significant role in the relationship of FDI and economic growth.

We used the generalized method of moments (GMM) to highlight the effect of FDI and human capital on economic growth using data from the World Bank and other sources. To verify the existence of a threshold effect on human capital, we used a fixed-effect threshold modeling in panel data (Wang, 2015). The rest of this paper is structured around three points, namely the literature review, the specification of the model and the presentation, and interpretation of the results.

\section{Literature Review}

\subsection{Theoretical Review}

The theory of the neoclassical growth (Solow, 1956; Swan, 1956) declares that the accumulation of physical capital doesn't explain the strong per capita output growth over time due to geographical variances, differences in income and levels of technological advancement, and the nonexistence of positive economic externalities. Solow's model shows that long-term economic growth can't rely solely on the accumulation of physical capital (the problem of diminishing return on capital). The rise in fixed investments without a concomitant increase in the working population would only lead to a transitory acceleration in per capita production. Since the labor force of an economy cannot be increased without limit, another factor can produce and maintain the high rate of economic growth. The technological progress is one of the main sources of long-term

${ }^{3}$ Exploration of data from the World Development Indicators (The World Bank data) by author. 
growth also called the "residue" of economic growth that can't be attributed to the growth of capital or labor. This residue, called the "Solow residue" or "total factor productivity", is linked to an increase in knowledge, the discovery of new ideas, or an increase in economic efficiency (Aslam, Hassan, \& Sakar, 2013). Nevertheless, Solow's growth model doesn't explicate the source of this technological progress, making it exogenous to the process of economic growth.

By the mid-1980s, a new growth theory proposed by Romer (1986, 1987), Lucas $(1988,1990)$, and Mankiw et al. (1992) suggested economic growth rates to be endogenous. The assumption of this theory was that increasing returns to scale can be possible by maintaining increased investments in human and physical capital. These investments would create a permanent increase in the rate of economic growth. Endogenous growth theories emphasize the role of human capital (Lucas, 1990). Differences in productivity between countries are subject to differences in skill levels and ability of workers to use technology. Another important argument of these theories concerns the effect of technological "spillovers" on economic growth (Aghion \& Howitt, 1998; Howitt, 2000). These effects are indirectly associated with the effects of technological change on the economy. Therefore, endogenous growth theory focuses on the externalities resulting from accumulation of human and physical capital as the main forces of long-term productivity growth (Aslam, Hassan, \& Sakar, 2013).

To the new economic growth model, FDI can affect growth endogenously if increasing returns to production via externalities and spillover effects are generated (Aslam et al., 2013). Promoters of this school of thought argue that, unlike physical objects, knowledge and technology are not linked by falling returns to scale but are rather the engines of the growth process. According to Solow, 1957 and De Mello, 1997, this contrasts with the exogenous economic growth model in which the impact of FDI on the growth rate of production is limited by the existence of falling returns on physical capital, in which FDI affects only the level of income and not long-term growth.

According to the endogenous growth theory, the falling profits to physical capital can be postponed altogether when human capital is added to the production function alongside physical capital and unskilled labor (Aslam, Hassan, \& Sakar, 2013). Thus human capital stock's limits the absorptive capacity of its economy (Borensztein et al., 1998). The workforce value depends on accumulated experience and the education system. This quality of work will determine an economy's ability to adapt old technologies to new learning and the creation of new ideas. In other words, high-quality human capital is a major factor capable of absorbing the technological spillovers resulting from FDI and is therefore a determining factor of the effects of FDI on economic growth.

FDI can contribute significantly to human capital in several ways, such as the introduction of new management practices and organizational arrangements as well as the training of workers. The impact on R\&D could stimulate innovation and thus contribute to the host country's growth (Grossman \& Helpman 1991; 
Calvo \& Robles, 2003). Therefore, factors such as increasing returns to scale, innovation, trade openness, $\mathrm{R} \& \mathrm{D}$, and human capital formation are key factors in explaining the growth process.

In sum, it should be mentioned that human capital is an important absorber of technology contributed by multinationals as long as it makes a significant contribution to economic growth and local technological development is not established. To be truly competitive, foreign technologies must be absolutely innovative. In our model based on the theory of endogenous growth, FDI would have two effects on economic growth: The first is a direct effect of the increase in the capital stock in terms of financing capital formation. FDI contributes directly to growth in the same way as domestic investment. The second impact is indirect via the spillover effect. It is assumed here that FDI is more productive than domestic investment. FDI promotes growth by strengthening human capital and encouraging new technologies in the host country by disseminating management skills, marketing techniques, workforce training, and skills acquisition, as well as stimulating R\&D activities and promoting exports. Spillovers from technology and knowledge will offset the effects of lower returns on capital and keep the economy on track for long-term growth. Human capital is assumed to directly affect the growth of local workers who learn technology and new knowledge from multinational companies.

\subsection{Empirical Review}

Empirical review on the role of human capital in the FDI-economic growth relationship highlights several works that we summarize here in two categories: on the one hand, works affirming a positive effect of human capital and FDI, and, on the other, works concluding that there is no relationship or negative effect of FDI on economic growth in the presence of human capital.

In the first category, Goumrhar (2017), using a sample of 65 developing countries over the period 1985-2015, through GMM, came to the conclusion that FDI acts positively and has a significant impact on economic growth. This author used trade openness, gross fixed capital formation, and government consumption as a control variable to reach the conclusion that human capital reinforces the positive effect of FDI on the economic growth of developing countries. Also, the impact of human capital (measured by the average number of years of study) was found to be positive and significant on the economic growth of the countries sampled. However, this impact was conditioned by the existence of a threshold below which education has no effect on the growth of developing countries.

The positive role of human capital in the FDI-economic growth relationship was also found by Azam et al. (2015), who carried out a panel data study for 34 developing countries covering the period 1981-2013 and using a fixed-effect estimate. Likewise, Abdeljabbar and Hicham (2010) applied the GMM method to 30 developing countries in Africa, Asia, and Latin America over a period from 1982 to 1997 to demonstrate a direct positive and significant effect of FDI on 
economic growth. These authors further emphasized that the role of human capital in the FDI-economic growth relationship ${ }^{4}$ is only perceptible for developing countries after a minimum level of human capital accumulation. $\mathrm{Li}$ and Tanna (2019), using GMM system panel data estimates of 51 developing countries for the period 1984-2010, found that FDI has a positive role on economic growth in the relationship, including capital human and institutions. However, these authors found that FDI acts more on economic growth through institutions than through the accumulation of human capital.

In the second category of studies ruling on a negative or no effect, we found that of Cleeve, Debrah and Yiheyis (2015), who conducted a dynamic panel data study of African countries over the period 1980-2012 in order to see if FDI inflows in African countries improved the skills of workers. After estimating several models of FDI, these authors did not find evidence of improved human capital, probably because of the quality of FDI entering African countries. In the same perspective, Demir and Duan (2018) questioned the quality of FDI inflows from the North to the South. These authors, by controlling the aggregation bias of FDI flows and the heterogeneity of 240 countries of origin and 108 host countries within and between the North and the South over the period 1990-2012, using various estimation techniques, found no significant effect of bilateral FDI flows on the productivity growth of the host country or on the productivity gap between the host and border countries. These authors also found no evidence of a positive effect of FDI inflows on North-South human capital growth. Using panel data analysis based on a theoretical model of endogenous growth, Demissie (2015) examined the role of human capital in the FDI-economic growth relationship through numerous macroeconomic aggregates of 56 developing countries between 1985-2014. It resulted in a very significant negative effect of FDI on the economic growth of low-income countries. The author's analysis of the FDI-human capital interaction effect suggests the existence of a minimum human capital threshold above which the role of FDI becomes significant.

Overall, this review of the literature on the role of human capital in the FDI-economic growth relationship reveals a predominance of two theoretical currents: the endogenous growth model and the MRW model. However, recent empirical works on this issue in developing economies that have used one of these two frameworks are in agreement on the existence of a human capital threshold, above which states would be FDI attractiveness, that is favorable to economic growth via technological spillovers.

\section{Model Specification}

\subsection{Theoretical Model}

To analyze the role of human capital in the FDI-economic growth relationship,

${ }^{4}$ Abdeljabbar and Hicham (2010) used as control variables the following: GFCF, exports, rate of population growth, rate of growth of cultivable land, GDP per capita of the first period, and the area of each country in the sample. 
we start from the neoclassical two-factor growth model based on the Cobb-Douglas type production function below:

$$
Y(t)=A * K(t)^{\alpha} L(t)^{1-\alpha},
$$

with $0<\alpha<1$.

This growth model proposed by Solow (1956) and Swan (1956) assumes constant technical progress $(A)$, the labor supply $(L)$, which grows at the rate $\mathrm{n}$, an exogenous savings rate $(s)$, and a constant rate of depreciation denoted $(\delta)$. Mankiw et al. (1992) augmented model (1) by adding human capital $(H)$ as a third factor of production. The model becomes

$$
Y(t)=A(t) * K(t)^{\alpha} * H(t)^{\beta} * L(t)^{1-\alpha-\beta},
$$

with $0<\alpha<1 ; 0<\beta<1 ; \alpha+\beta<1$, where $Y$ is the volume of production, $K$ is the stock of physical capital, $H$ is the stock of human capital, $L$ is the supply of labor, and $A$ is the level of technology. $\alpha$ and $\beta$ are elasticity coefficients associated respectively with physical and human capital.

We also know that $K$ can be divided into domestic investment (ID) and FDI investment (IDE; Lleshaj and Malaj, 2016). To highlight the role of human capital in the FDI-economic growth relationship, we restrict the capital stock $(K)$ to FDIs. Applying the natural logarithm gives the following specification:

$$
\ln Y(t)=\ln A(t)+\alpha \ln I D E(t)+\beta \ln H(t)+\lambda \ln L(t),
$$

where $\lambda=1-\alpha-\beta$.

\subsection{Econometric Specification}

Many studies have analyzed the FDI-human capital-economic growth relationship via a panel analysis. However, the autoregressive nature of economic growth directs most studies toward a dynamic panel data model. Blundell et al. (2012), highlighting the limitations of the standard dynamic model estimator, proposed the use of a generalized system moment estimator.

Indeed, the dynamic model of panel data starts from an autoregressive model of the form:

$$
\begin{gathered}
y_{i t}=\alpha y_{i t-1}+\beta^{\prime} x_{i t}+u_{i t}, \\
u_{i t}=\eta_{i}+v_{i t} .
\end{gathered}
$$

For $i=1, \cdots, N$ and $t=2, \cdots, T$, where $\eta_{i}+v_{i t}$ is the decomposition of the error term; $N$ is large, $T$ is fixed, and $|\alpha|<1$. The introduction of $x_{i, t-1}$ permits the following autoregressive model in panel data:

$$
y_{i t}=\alpha y_{i t-1}+\beta^{\prime \prime} x_{i t}+\beta^{\prime \prime \prime} x_{i t-1}+\eta_{i}+v_{i t},
$$

whose reduced form is

$$
y_{i t}=\alpha y_{i t-1}+\beta^{\prime} x_{i t}+f_{i}+\zeta_{i t} .
$$

The first-order autoregressive model of a dynamic panel has the following form:

$$
y_{i t}=\alpha y_{i t-1}+u_{i t},
$$




$$
u_{i t}=\eta_{i}+v_{i t} .
$$

This model provides the following standard assumptions:

$$
E\left(\eta_{i}\right)=0, E\left(v_{i t}\right)=0, E\left(v_{i t} \eta_{i i}\right)=0 \text { for } i=1, \cdots, N \text { et } t=2, \cdots, T .
$$

The presence of the term $y_{i t-1}$ to the right of Equation (5) introduces endogeneity, and some basic assumptions are no longer verified.

$$
\begin{gathered}
E\left(v_{i t} v_{i s}\right)=0 \text { for } i=1, \cdots, N \text { et } t \neq s . \\
E\left(y_{i 1} v_{i t}\right)=0 \text { for } i=1, \cdots, N \text { et } t=2, \cdots, T .
\end{gathered}
$$

The standard assumptions (7), (8), and (9) imply restrictions on the conditional moments sufficient to identify and estimate $\alpha$ for $T \geq 3$. Baltagi (1995) proposed extension of the restrictions on the initial conditions of the model by a process of stationary mean and covariance, such as

$$
y_{i 1}=\frac{\eta_{i}}{1-\alpha}+\varepsilon_{i 1} \text { for } i=1, \cdots, N,
$$

with

$$
\begin{gathered}
E\left(\varepsilon_{i 1}\right)=E\left(\eta_{i} \varepsilon_{i}\right)=0 \text { for } i=1, \cdots, N, \\
E\left(v_{i 1}^{2}\right)=\sigma_{v}^{2} \text { for } i=1, \cdots, N \text { et } t=2, \cdots, T, \\
E\left(\varepsilon_{i 1}^{2}\right)=\frac{\sigma_{v}^{2}}{1-\alpha^{2}} \text { for } i=1, \cdots, N .
\end{gathered}
$$

There are no restrictions on the process of generating initial conditions, and the counterpart of the autoregressive error model (4)-(9) implies the following orthogonality conditions:

$$
m_{d}=(T-1)(T-2),
$$

such that

$$
E\left(y_{i, t-s} \Delta u_{i t}\right)=0 \text {; pour } t=3, \cdots, T \text { et } 2 \leq s \leq t-1 \text {, }
$$

where $\Delta u_{i t}=u_{i t}-u_{i t-1}$. This only depends on the presumed absence of serial correlations in the time varying perturbations $v_{i t}$ as well as restrictions (9). The moment restrictions in (12) can be expressed more compactly as

$$
E\left(Z_{d i}^{\prime} \Delta u_{i}\right)=0,
$$

where $Z_{d i}$ is the $(T-2) \times m_{d}$ matrix given by

$$
Z_{d i}=\left[\begin{array}{ccccccc}
y_{i 1} & 0 & 0 & \cdots & 0 & \cdots & 0 \\
0 & y_{i 1} & y_{i 2} & \cdots & 0 & \cdots & 0 \\
\vdots & \vdots & \vdots & \ddots & \vdots & \ddots & \vdots \\
0 & 0 & 0 & \cdots & y_{i 1} & \cdots & y_{i T-2}
\end{array}\right],
$$

and $\Delta u_{i}$ is the $(T-2)$ vector $\left(\Delta u_{i 3}, \Delta u_{i 4}, \cdots, \Delta u_{i x}\right)^{\prime}$. The GMM first-difference estimator is based on the conditional moments that minimize the quadratic distance $\Delta u^{\prime} Z_{d} W_{N} Z_{d}^{\prime} \Delta u$ for the parameter $W_{N}$, where $Z_{d}^{\prime}$ is the $m_{d} \times N(T-2)$

${ }^{5}$ Ahn et Schmidt (1995). 
matrix $\left(Z_{d 1}^{\prime}, Z_{d 2}^{\prime}, \cdots, Z_{d N}^{\prime}\right)$ and $\Delta u^{\prime}$ is the $N(T-2)$ vector $\left(\Delta u_{1}^{\prime}, \Delta u_{2}^{\prime}, \cdots, \Delta u_{N}^{\prime}\right)$. This allows one to have the GMM estimator $\alpha$ as a first difference, such as

$$
\hat{\alpha}=\left(\Delta y_{-1}^{\prime} Z_{d} W_{N} Z_{d}^{\prime} \Delta y_{-1}\right)^{-1} \Delta y_{-1}^{\prime} Z_{d} W_{N} Z_{d}^{\prime} \Delta y,
$$

where $\Delta y_{i}^{\prime}$ is the $(T-2)$ vector $\left(\Delta y_{i 3}, \Delta y_{i 4}, \cdots, \Delta y_{i x}\right), \Delta y_{i-1}^{\prime}$ is the (T-2) vector $\left(\Delta y_{i 2}, \Delta y_{i 3}, \cdots, \Delta y_{i x-1}\right)$, and $\Delta y_{i-1}^{\prime} . \Delta y$ and $\Delta y_{-1}$ have the same behavior as $\Delta u$ on individuals.

Moreover, apart from standard assumptions, Blundell et al. (2012) showed that

$$
E\left(\eta_{i} \Delta y_{i 2}\right)=0 \text { for } i=1, \cdots, N,
$$

considering the difference (4)-(9), which specifies $y_{i 2}$, knowing that $y_{i 1}$, condition (13), is a restriction on the process of the initial condition of $y_{i 1}$. When this restriction matches the standard GMM assumptions stated in (7), (8), and (9), the linear conditional moments below are valid:

$$
E\left(u_{i t} \Delta y_{i, t-1}\right)=0 ; \text { pour } t=3,4, \cdots, T .
$$

This hypothesis (14) corrects the endogeneity of the dependent variable, which is replaced by an instrument. The computation of the GMM estimator in a system via the method of linear conditional moments (12) and (14) can be based on a stacked system comprising all of the T-2 equations in first difference and the $T-2$ equations in a level corresponding to the periods $t=3, \cdots, T$, for which the instruments are observed. Taking into account this combination of conditional moments, Blundell et al. (2012) proposed an estimate taking into account the standard GMM level estimator based on the conditional moments $m_{l}=0.5(T-1)(T-2)$ and based on the assumption that

$$
E\left(u_{i t} \Delta y_{i, t-s}\right)=0 \text { for } t=3, \cdots, T \text { and } 1 \leq s \leq t-2 .
$$

This means $E\left(Z_{l i}^{\prime} u_{i}\right)=0$, where $Z_{l i}$ is the matrix $(T-2) \times m_{l}$, such that

$$
Z_{l i}=\left[\begin{array}{ccccccc}
\Delta y_{i 2} & 0 & 0 & \cdots & 0 & \cdots & 0 \\
0 & \Delta y_{i 2} & \Delta y_{i 3} & \cdots & 0 & \cdots & 0 \\
\vdots & \vdots & \vdots & \ddots & \vdots & \ddots & 0 \\
0 & 0 & 0 & \cdots & \Delta y_{i 2} & \cdots & \Delta y_{i, T-1}
\end{array}\right] .
$$

The resulting $m_{s}=0.5(T+1)(T-2)$ conditional moments are as follows:

$$
\begin{gathered}
E\left(y_{i, t-s} \Delta u_{i t}\right)=0 ; \text { for } t=3,4, \cdots, T \text { and } 2 \leq s \leq t-1, \\
E\left(u_{i t} \Delta y_{i, t-1}\right)=0 ; \text { for } t=3, \cdots, T .
\end{gathered}
$$

These moments can be summarized by the expression

$$
E\left(Z_{s i}^{\prime} q_{i}\right)=0 \text {, }
$$

where $q_{i}=\left[\begin{array}{c}\Delta u_{i} \\ u_{i}\end{array}\right]$, 


$$
Z_{s i}=\left[\begin{array}{cc}
Z_{d i} & 0 \\
0 & Z_{l i}^{p}
\end{array}\right]=\left[\begin{array}{ccccc}
Z_{d i} & 0 & 0 & \cdots & 0 \\
0 & \Delta y_{i 2} & 0 & \cdots & 0 \\
0 & 0 & \Delta y_{i 3} & \cdots & 0 \\
\vdots & \vdots & \vdots & \ddots & 0 \\
0 & 0 & 0 & \cdots & \Delta y_{i, T-1}
\end{array}\right],
$$

with $Z_{l i}^{p}$ is a no redundant subset of $Z_{l i}$.

The GMM system estimator is ultimately a linear combination of generalized moments similar to the double least squares estimator given by

$$
\hat{\alpha}=\left(q_{-1}^{\prime} Z_{s}\left(Z_{s}^{\prime} Z_{s}\right)^{-1} Z_{s}^{\prime} q_{-1}\right)^{-1} q_{-1}^{\prime} Z_{s}\left(Z_{s}^{\prime} Z_{s}\right)^{-1} Z_{s}^{\prime} q .
$$

Thus, the GMM system estimator can improve the poor performance of the standard GMM estimator for a highly autoregressive panel series. This estimator is based on restrictions to the initial conditions process. Because it relies on the GMM first-difference and level estimators, this estimator exhibits substantial asymptotic efficiency gains (Blundell et al., 2012). Therefore, this is why we chose it within the framework of the present research.

\subsection{Empirical Specification}

This study consists of estimating the impact of human capital in the FDI-economic growth relationship, here represented by GDP per capita. The initial model therefore involves three variables: FDI, human capital, and GDP. In this study, following Iqbal, Ahmad, Haider and Anwar (2013), we used the Cobb-Douglas production function stated as follows:

$$
Y(t)=A(t) * K(t)^{\alpha} * H(t)^{\beta} * L(t)^{1-\alpha-\beta} \text { avec } 0<\alpha<1 ; 0<\beta<1 ; \alpha+\beta<1 .
$$

For study purposes and in order to incorporate all of the model variables, we made the following modifications:

$$
P I B=f\left(F B C F, y r s_{s c h}, I D E, \text { Cons }_{p u b}, O u v_{C o m}, \text { Pop_urb }\right) .
$$

Arellano and Bond (1991) practical approach to GMM estimation in dynamic panel data proposes the application of the logarithmic transformation to Equation (19) and the attainment of the following four specifications:

$$
\begin{aligned}
& \log P I B_{i t}=\alpha_{0}+\alpha_{1} \log P I B_{i, t-1}+\alpha_{2} \ln I D E_{i t}+\alpha_{3} F B C F_{i t}+\alpha_{4} \text { Cons } \_u b_{i t} \\
& +\alpha_{5} \ln O u v_{C} \text { com }_{i t}+\alpha_{6} \ln \text { Pop_urb }{ }_{i t}+\eta_{i}+v_{i t} \\
& \log P I B_{i t}=\varkappa_{0}+\varkappa_{1} \log P I B_{i, t-1}+\varkappa_{2} \ln y r s_{-} s c h_{i t}+\varkappa_{3} F B C F_{i t}+\varkappa_{4} \text { Cons_pub } \\
& +\varkappa_{5} O u v \_ \text {com }_{i t}+\varkappa_{6} \ln P o p \_u r b_{i t}+\pi_{i}+\mu_{i t} \\
& \log P I B_{i t}=\beta_{0}+\beta_{1} \log P I B_{i, t-1}+\beta_{2} \ln I D E_{i t}+\beta_{3} \ln y r s_{-} s c h_{i t}+\beta_{4} F B C F_{i t} \\
& +\beta_{5} \text { Cons_pub } b_{i t}+\beta_{6} \text { Ouv_com }_{i t}+\beta_{7} \ln \text { Pop } \_u r b_{i t}+\eta_{i}+\varepsilon_{i t} \\
& \log P I B_{i t}=\delta_{0}+\delta_{1} \log P I B_{i, t-1}+\delta_{2} \ln I D E * y r s_{-} s c h_{i t}+\delta_{3} \ln y r s_{-} s c h_{i t} \\
& +\delta_{4} F B C F_{i t}+\delta_{5} \text { Cons_pub } b_{i t}+\delta_{6} \ln O u v \_c o m_{i t} \\
& +\delta_{7} \text { Pop_urb } b_{i t}+\theta_{i}+v_{i t}
\end{aligned}
$$


with $\eta_{i}, \pi_{i}, \eta_{i}, \theta_{i}$ : individual specific effects, and $v_{i t}, \mu_{i t}, \varepsilon_{i t}, v_{i t}$ : perturbations or residue of the model. The $\delta_{i}, \beta_{i}, \varkappa_{i}$, and $\alpha_{i}$ are the parameters to be estimated.

- $\log P I B_{i t}$ is the logarithm of the GDP per capita in purchasing power parity (PPP) at the constant price base 2005.

- $\log P I B_{i, t-1}$ is the logarithm of the level of lagged GDP per capita.

- $F B C F_{i t}$ is the gross fixed capital formation (expressed as a percentage of GDP), used as a proxy for physical capital.

- $\ln I D E_{i t}$ is the logarithm of incoming FDI (expressed in millions of dollars).

- InOuv_com ${ }_{i t}$ is the logarithm of the degree of trade openness of the economy (the sum of the volume of exports and imports of goods and services) as a percentage of real GDP.

- $\ln$ Cons $\_u b_{i t}$ is the logarithm of the general government final consumption expenditure as a percentage of GDP (World Development Indicators, 2013).

- $\ln y r s_{-} s c h_{i t}$ is the logarithm of the average number of years of schooling, used as an index of human capital (Barro \& Lee, 2010).

- $\ln I D E * y r s \_s c h_{i t}$ is the logarithm of the interaction term between investment in human capital and FDI. This term reflects the complementarity between the two components through the canon of new technologies and R\&D on per capita GDP.

- $\ln$ Pop_urb $b_{i t}$ is the logarithm of the urban population expressed as a percentage of the total population.

Equation (20) allows one to understand the effects of FDI on economic growth in the presence of exogenous variables but without the effect of human capital. Equation (21) aims to capture the effects of human capital on economic growth in the presence of exogenous variables but not the effect of FDI. Equation (22) jointly measures the effects of FDI and human capital on the area's economic growth. In addition, Equations (20) and (21) and (22) make it possible to highlight the role of human capital in the FDI-economic growth relationship. Equation (23) highlights the effect of FDI-human capital interaction on economic growth. This procedure shows whether the two variables jointly affect growth by themselves or through the interaction term.

\subsection{Data Sources}

This paper uses data from three sources namely the World Development Indicator, the Penn World Table and the United Nations Conference on Trade and Development (UNCTADSTAT). Table 1 below indicates the variables used in this paper as well as the sources from which these data are drawn. These data relate to 5 countries among the 6 in the CEMAC zone, namely Cameroon, Congo, Gabon, CAR and Chad. Equatorial Guinea was removed for lack of information on the human capital variable. The initial series are ranged from 1970 to 2017. The years 2018 and 2019 were completed by moving average to obtain complete series from 1970 to 2019 , i.e. 50 years of observation per country. 
Table 1. Variable dictionary.

\begin{tabular}{|c|c|c|}
\hline Variable names & Label of variable & Source of data \\
\hline pib_hab & $\begin{array}{l}\text { Gross domestic product per capita in purchasing } \\
\text { power parity PPP at constant price base } 2010\end{array}$ & $\begin{array}{l}\text { World Development } \\
\text { Indicators (WDI) }\end{array}$ \\
\hline ide & $\begin{array}{l}\text { Inward foreign direct investment, } \\
\text { expressed in millions of dollars }\end{array}$ & UNCTADSTAT \\
\hline$f b c f$ & $\begin{array}{l}\text { Gross fixed capital formation, expressed as a percent } \\
\text { of GDP, used as a proxy for physical capital. }\end{array}$ & WDI \\
\hline ouv_com & $\begin{array}{l}\text { Degree of trade openness of the economy (the sum of } \\
\text { the volume of exports and imports of goods and } \\
\text { services) as a } \% \text { of real GDP. }\end{array}$ & WDI \\
\hline con_pub & $\begin{array}{l}\text { Government final consumption expenditure in } \\
\text { percent of GDP }\end{array}$ & WDI \\
\hline Pop_urb & Urban population, in $\%$ of total population & WDI \\
\hline yrs_sch & $\begin{array}{l}\text { Human capital index, based on the average } \\
\text { years of schooling (Barro/Lee, 2010). }\end{array}$ & $\begin{array}{l}\text { Penn world Table } \\
\text { (PWT) }\end{array}$ \\
\hline$I D E^{*} y r s \_s c h$ & $\begin{array}{l}\text { interaction term between investment } \\
\text { between human capital and FDI }\end{array}$ & WDI and PWT \\
\hline
\end{tabular}

Source: Author.

To overcome the problems of multicollinearities between the variables, we estimated the correlation coefficients between the model variables. The results obtained reveal a strong correlation between the IDE variable and the interaction term (IDE $*$ yrs_sch). To remedy this problem, we removed the IDE from the model (23) that uses the interaction term (Table 2).

\section{Presentation and Interpretation of the Results}

Table 3 presents the results of the estimations of the dynamic model by the GMM system obtained by using the xtabond2 function in stata, proposed by Roodman (2009). It is necessary to take into account, in the model, a lagged value of the endogenous variable LnPIB_it-1, since this is an autoregressive type of dynamic model. The introduction of the lag makes it possible to check whether the economic growth of a year is influenced by that of past years. In addition, in the equation for the analysis of growth, the lagged variables allow us to better take into account the phased effects of growth-promoting policy decisions that often do not have immediate effects on the economy.

The Arellano and Bond (1991) tests of first- and second-order first-difference autocorrelation of the residuals as well as the Sargan/Hansen overidentification test (tests on instruments), presented in the last three lines of Table 3, provide important information. As we show, the serial autocorrelation test of the Arellano and Bond residuals in first difference in the four models validates the specification of the models by GMM, hence the absence of second order autocorrelation. Sargan's statistic validates the choice of instruments. The $p$ values of the 
Table 2. Matrix of correlation.

\begin{tabular}{|c|c|c|c|c|c|c|c|c|}
\hline & lnpibhan & lnide & lnyrssch & lnpopurb & $\operatorname{lnfbcf}$ & lnconpub & lnouvcom & lnyrside 2 \\
\hline npibhan & 1 & & & & & & & \\
\hline lnide & $0.4372^{*}$ & 1 & & & & & & \\
\hline lnyrssch & $0.4366^{*}$ & $0.7455^{\star}$ & 1 & & & & & \\
\hline lnpopurb & $0.7320^{*}$ & $0.4556^{*}$ & $0.5526^{*}$ & 1 & & & & \\
\hline $\operatorname{lnfbcf}$ & $0.6397^{\star}$ & $0.4506^{*}$ & $0.2789^{\star}$ & $0.3952^{*}$ & 1 & & & \\
\hline lnconpub & $-0.797^{\star}$ & $-0.427^{*}$ & $-0.465^{*}$ & $-0.6124^{*}$ & $-0.530^{*}$ & 1 & & \\
\hline lnouvcom & $0.647^{*}$ & $0.3984^{*}$ & $0.3794^{*}$ & $0.5089^{*}$ & $0.6327^{*}$ & $-0.6654^{*}$ & 1 & \\
\hline lnyrside2 & $0.4344^{*}$ & $0.8966^{*}$ & $0.9181^{*}$ & $0.5267^{\star}$ & $0.3229^{*}$ & $-0.4458^{*}$ & $0.3952^{*}$ & 1 \\
\hline
\end{tabular}

Source: Author.

Table 3. Dynamic Panel Model of Arellano and Bond (1991) (Two-step GMM System), Dependent Variable: Logarithm of GDP Per Capita PPP (Constant Price Base 2005).

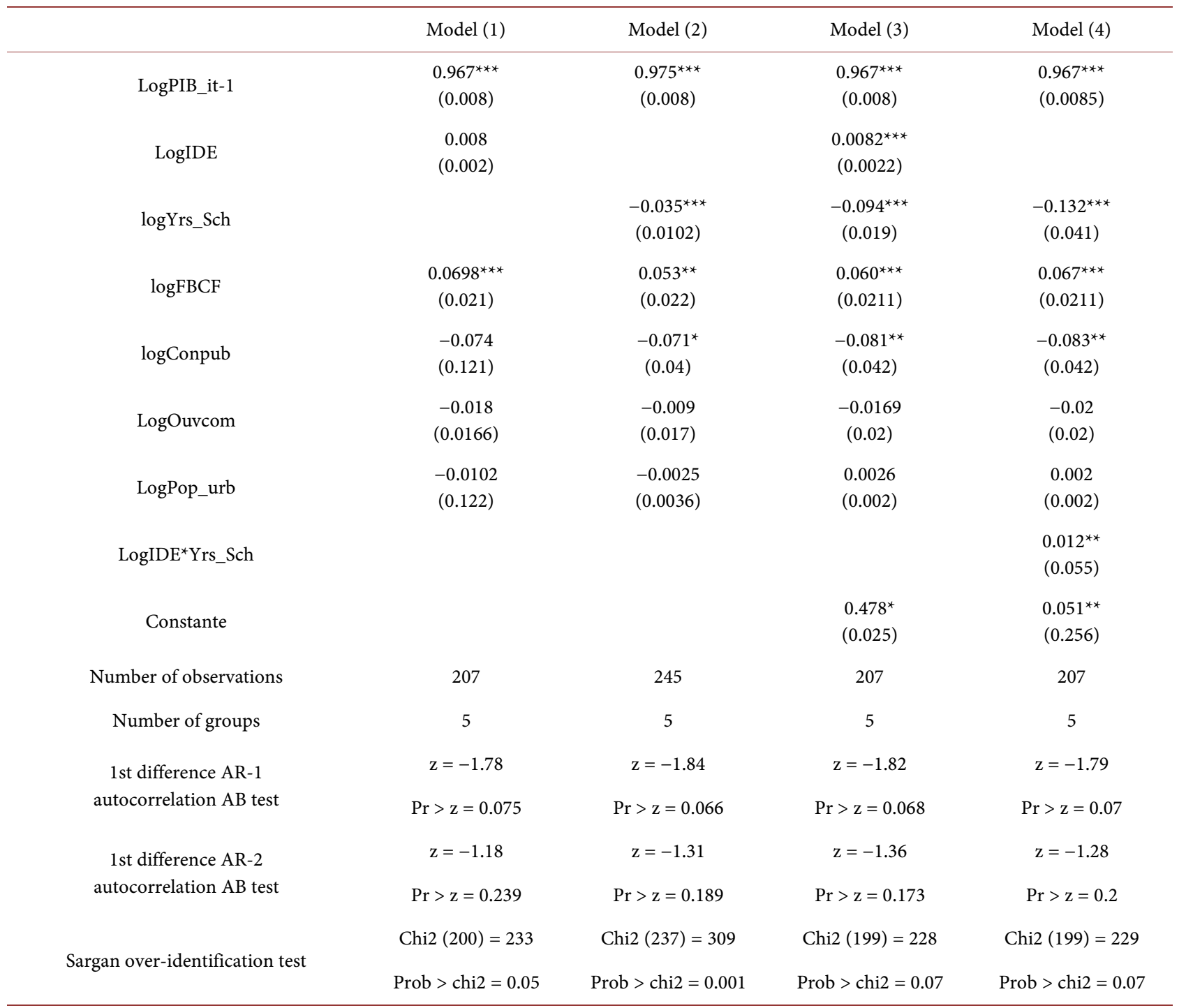

Source: Author. Notes: ${ }^{\star} \mathrm{p}<0.1,{ }^{* *} \mathrm{p}<0.05,{ }^{* *} \mathrm{p}<0.01$. 
equations of models (1), (2), (3), and (4), are less than 10 percent, thus allowing one to affirm that the instruments used are meaningful and valid. The GMM model can then be used to analyze the human capital-FDI-economic growth relationship for the case of CEMAC countries.

To determine the degree of integration of the series used in the model, we performed three stationarity tests. These are the Levin, Lin and Chu (2002) test, the Harris and Tzavalis (1999) test, and the Breitung (2000) test. Based on these three tests, all of the series are stationary in level, except for the series of GDP per capita (lnpibhan) and the interaction factor between FDI and human capital (lnyrside 2), which are stationary in difference first.

Our results indicate that FDI does not contribute in a statistically significant way to the economic growth of the CEMAC countries when human capital is not taken into account (Model 1). Indeed, even if the coefficient associated with this variable is positive, the associated probability is statistically insignificant. However, the introduction of the variable measuring human capital in the model (Model 3) improves the effect of FDI on human capital. Thus, an increase in FDI of 1 percent leads to an increase of 0.8 percent of GDP per capita in the CEMAC zone, in the presence of human capital. This result highlights the important role played by education of the population, even of low quality (Barro \& Lee, 2010), in maintaining the effects of FDI on the economic growth of host countries in the CEMAC countries.

Regarding human capital, the results indicate a very significant and negative coefficient, whatever the model (Models 2, 3, or 4). In other words, the education efforts in CEMAC translate into negative returns on the economic growth of the area. The priorities accorded by CEMAC governments to primary education, following the 1990 Jomtien conference, may partly explain the low funding granted to secondary and especially higher education levels (Mboko, 2018). However, the return on investment in education is only noticeable on economic growth from a secondary level (Xu, 2000).

\section{Discussion}

The results of the different estimates by GMM methods of the four models show a change in the effect of FDI on economic growth depending on the impact of human capital (Barro \& Lee, 2010). When FDIs are analyzed without taking human capital into account, their effect on economic growth in CEMAC zone is not significant. This is in contradiction with the work of Makki and Somwaru (2004) who found a positive effect of FDI on the economic growth of 66 developing countries. However, the addition of human capital (Model 3) improves the significance of the positive effect of FDI on economic growth. In other words, even though human capital in CEMAC zone is particularly low, it helps to justify the presence of foreign investment in the area. This result is consistent with the work of de Lumengo and Maphelane (2017) which showed that, contrary to countries with abundance of skills, in countries with skills shortages, it is 
in fact the evolution of the stock of human capital or the accumulation of human capital that matters in determining the effects of IDE on the PTF.

The lack of a positive effect of FDI can be explained by the nature of FDI that enters CEMAC zone. Indeed, as Gui-Diby and Renard (2015) have pointed out, an essential part of FDI entering Africa does not contribute to its industrialization, not only because of institutional constraints but also and above all because of the preponderance of FDI with low added value (exploitation of raw materials). Historically, FDI has been concentrated in highly capital-intensive sectors such as oil exploitation or solid mining. This is particularly true in the CEMAC zone. In fact, Central Africa has oil-producing countries (Congo, Gabon, and Chad Equatorial Guinea) and agricultural countries (CAR and Cameroon) with the emergence of a small industry around the city of Douala. These countries' economic configurations adequately match the conclusion of Gui-Diby and Reanrd (2015) about Africa. By focusing attention on the expected effects of short-term growth, the countries of the zone have not sufficiently emphasized the role of FDI's quality on the global integration strategy of their economies vis-à-vis the world economy.

The results established that the human capital has a significant negative effect on economic growth (Models 2, 3, and 4). This is a major point of our research. Indeed, despite the public investments in education made by CEMAC governments in recent decades, human capital in the economic zone seems not to have reached a sufficient level to start producing the expected returns in economic growth. This is because these investments in education have mostly focused on the goal of Education For All (EFA). However, as Grossman and Helpman (1991) indicated, it is high-value-added FDI, absorbing a highly qualified workforce that makes it possible to capture the technological spillovers from both FDI and human capital on economic growth. The scale of technological spillovers from FDI is closely correlated with the absorption capacity of the host country, including its average stock of human capital (Blomström \& Kokko, 2003).

On the other hand, the application of a regime change model $^{6}$ (Wang, 2015) showed the absence of the human capital threshold effect necessary for the attractiveness of FDI. This model also proved the absence of a threshold effect of FDI necessary for the transmission of new knowledge and practices in the CEMAC zone. These two results confirm our previous analyses. On the one hand, they show that human capital in the CEMAC zone does not make an attractive report vis-à-vis foreign investors. On the other hand, FDIs present in the CEMAC zone do not appear to promote the transmission of knowledge and practices (Demissie, 2015; Demir \& Duan, 2018). This could essentially be low value-added FDI (Gui-Diby \& Renard, 2015). Thus, as proved by Xu (2000), the positive externalities allowed by FDI are more likely to appear in countries that have already reached a certain threshold of development of their human capital. This author was able to establish this threshold at 1.9 years of high school.

${ }^{6}$ See Appendices $1-3$. 
However, in the case of CEMAC zone, the threshold found in this research was established at 1.5 years of secondary education. Based on these results, it seems clear that the CEMAC countries, taken as an entity with generally deteriorated educational systems, have not yet reached the human capital threshold already determined by previous studies (Borensztein et al., 1998; Xu, 2000), which does not allow these countries to take full advantage of the positive externalities and advantages linked to FDI flows (Nelson \& Phelps, 1966; Benhabib \& Spiegel, 1994).

Another finding that emerges from our investigations reveals a positive and significant effect of the interactive term between education and FDI, which highlights that these two variables seem to maintain a complementary link between them. However, as the tests of threshold effects have shown, this effect is not systematic and on the other hand requires reaching a certain level of human capital stock in order to take full advantage of the positive externalities emanating from FDI.

\section{Conclusion and Policy Implications}

Our main objective in this research was to analyze the role of human capital in the FDI-economic growth relationship in the CEMAC zone. To do this, we used GMM to highlight the effect of FDI, via human capital, on economic growth based on data from the World Bank and other sources. To verify the existence of a threshold effect of human capital, we used a fixed-effect threshold modeling (Wang, 2015). In fact, after estimating the GMM, we performed a fixed-effects threshold modeling proposed Hansen (1999), using the xthreg procedure under stata (Wang, 2015) to determine the existence of any threshold effect of the human capital or FDI in their relation to economic growth.

Two major conclusions emerged from the results of this research. The first conclusion confirms our hypotheses in the sense that human capital in the CEMAC zone contributes significantly to improving the FDI-economic growth relationship. The second conclusion is that human capital has a negative and very significant effect on economic growth, all other things being equal. This result corroborates the threshold effect estimates, which have shown that CEMAC zone has not yet reached a level of human capital that allows it to take advantage of the economic benefits specific to the return on investment in education or through technological spillovers.

Two main implications in terms of economic policy emerge from this research. If the CEMAC countries wish to revive the economic growth of the zone via FDIs, it is necessary, in the short term, to seek the improvement of human capital through higher qualifying training. For example, this could include training courses containing a high dose of the use of information and communication technologies.

In the long run, it will be beneficial for the CEMAC countries to seek foreign financing with high added value. Indeed, a highly qualified workforce benefits 
the economic growth of the host country, the positive spillovers from FDI through the capacity for innovation, $R \& D$, and the speed of adaptation to new technologies (Borensztein et al., 1998; Xu, 2000; Blomström \& Kokko, 2003).

\section{Conflicts of Interest}

The author declares no conflicts of interest regarding the publication of this paper.

\section{References}

Abdeljabbar, A., \& Hicham, H. (2010). Investissement direct étranger, capital humain et croissance économique: Étude empirique en données de panel (Foreign Direct Investment, Human Capital and Economic Growth: Empirical Study in Panel Data) (pp. 1-24). AMSE WP N ${ }^{\circ}$ 2010-06. Moroccan Association of Economic Sciences. http://www.amse.ma/doc/WP_Abdouni_et_Hanchane.pdf

Aghion, P., \& Howitt, P. (1992). A Model of Growth through Creative Destruction. Econometrica, 60, 323-351. https://doi.org/10.2307/2951599

Aghion, P., \& Howitt, P. (1998). Endogenous Growth Theory. Cambridge, MA: MIT Press.

Arellano, M., \& Bond, S. (1991). Some Tests of Specification for Panel Data: Monte Carlo Evidence and an Application to Employment Equations. Review of Economic Studies, 58, 277-297. https://doi.org/10.2307/2297968

Aslam, H., Hassan, G., \& Shakar, A. (2013). Foreign Direct Investment, Human Capital and Economic Growth in Malaysia. Munich Personal RePEc Archive, MPRA Paper No. 51930.

Azam, M., Khan, S., Zainal, Z., Karuppiah, N., \& Khan, F. (2015). Foreign Direct Investment and Human Capital: Evidence from Developing Countries. Investment Management and Financial Innovations, 12, 155-162.

Baltagi, B. H. (1995). Econometric Analysis of Panel Data. Chichester: John Wiley.

Barro, R. J., \& Lee, J. W. (2010). A New Data Set of Educational Attainment in the World 1950-2010. Working Papers 15902, Cambridge, MA: National Bureau of Economic Research, Inc. https://doi.org/10.3386/w15902

Barro, R., \& Sala-i-Martin, X. (1992). Convergence. Journal of Political Economy, 100, 223-251. https://doi.org/10.1086/261816

Becker, G. (1964). Human Capital: A Theoretical Empirical Analysis with Special Reference to Education. New York: Columbia University Press.

Benhabib, J., \& Spiegel, M. (1994). The Role of Human Capital in Economic Development: Evidence from Aggregate Cross-Country Data. Journal of Monetary Economics, 34, 143-173. https://doi.org/10.1016/0304-3932(94)90047-7

Blomström, M., \& Kokko, A. (2003). The Economics of Foreign Direct Investments Incentives. Working Paper No. 9489, Cambridge, MA: National Bureau of Economic Research. https://doi.org/10.3386/w9489

Blundell, R., Bond, S., \& Windmeijer, F. (2012). Estimation in Dynamic Panel Data Models: Improving on the Performance of the Standard GMM Estimator. Working Paper No. 00/12, London: The Institute for Fiscal Studies.

Borensztein, E., De Gregorio, J., \& Lee, J.-W. (1998). How Does Foreign Direct Investment Affect Economic Growth? Journal of International Economics, 45, 115-135. https://doi.org/10.1016/S0022-1996(97)00033-0 
Breitung, J. (2000). The Local Power of Some Unit Root Tests for Panel Data. In B. H. Baltagi (Ed.), Advances in Econometrics, Volume 15: Nonstationary Panels, Panel Cointegration, and Dynamic Panels (pp. 161-178). Amsterdam: JAI Press. https://doi.org/10.1016/S0731-9053(00)15006-6

Calvo, M. B., \& Robles, B. S. (2003). Foreign Direct Investment as a Source of Endogenous Growth. Economics Working Paper No. 5/03, Cantabria: The University of Cantabria.

Cleeve, E. A., Debrah, Y., \& Yiheyis, Z. (2015). Human Capital and FDI Inflow: An Assessment of the African Case. World Development, 74, 1-14. https://doi.org/10.1016/j.worlddev.2015.04.003

De Mello, L. R. (1997). Foreign Direct Investment in Developing Countries and Growth: A Selective Survey. The Journal of Development Studies, 34, 1-34. https://doi.org/10.1080/00220389708422501

Demir, F., \& Duan, Y. (2018). Bilateral FDI Flows, Productivity Growth, and Convergence: The North vs. the South. World Development, 101, 235-249. https://doi.org/10.1016/j.worlddev.2017.08.006

Demissie, M. (2015). FDI, Human Capital and Economic Growth: A Panel Data Analysis of Developing Countries. Master Programs Thesis, Södertörns: Department of Economics, Södertörns University.

Feenstra, R. C., \& Markusen, J. (1994). Accounting for Growth with New Inputs. International Economic Review, 35, 429-447. https://doi.org/10.2307/2527062

Fraisse D’Olimpio, S. (2009). Les fondements théoriques du concept de capital humain (Theoretical Foundations of the Concept of Human Capital). SES. http://ses.ens-lyon.fr/ses/articles

Funke, M., \& Strulik, H. (2000). On Endogenous Growth with Physical Capital, Human Capital and Product Variety. European Economic Review, 44, 491-515. https://doi.org/10.1016/S0014-2921(98)00072-5

Goumrhar, H. (2017). Human Capital, Inequality and Economic Growth in Developing Countries: Analysis in Panel Data. International Journal of Innovation and Applied Studies, 20, 441-460.

Grossman, G., \& Helpman, E. (1991). Trade, Knowledge Spillovers, and Growth. European Economic Review, 35, 517-526. https://doi.org/10.1016/0014-2921(91)90153-A

Gui-Diby, S. L., \& Renard, M.-F. (2015). Foreign Direct Investment Inflows and the Industrialization of Africa. World Development, 74, 43-57.

https://doi.org/10.1016/j.worlddev.2015.04.005

Gundlach, E. (1995). The Role of Human Capitalin Economic Growth: New Results and Alternative Interpretations. Working Paper No. 659, Kiel: Kiel Institute of World Economics.

Hansen, B. E. (1999). Threshold Effects in Non-Dynamic Panels: Estimation, Testing, and Inference. Journal of Econometrics, 93, 345-368. https://doi.org/10.1016/S0304-4076(99)00025-1

Harris, R. D. F., \& Tzavalis, E. (1999). Inference for Unit Roots in Dynamic Panels Where the Time Dimension Is Fixed. Journal of Econometrics, 91, 201-226. https://doi.org/10.1016/S0304-4076(98)00076-1

Howitt, P. (2000). Endogenous Growth Theory and Cross Country Differences. American Economic Review, 90, 829-846. https://doi.org/10.1257/aer.90.4.829

Iqbal, N., Ahmad, N., Haider, Z., \& Anwar, S. (2013). Impact of Foreign Direct Investment (FDI) on GDP: A Case Study from Pakistan. International Letters of Social and 
Humanistic Sciences, 16, 73-80.

https://doi.org/10.18052/www.scipress.com/ILSHS.16.73

Levin, A., Lin, C.-F., \& Chu, C.-S. J. (2002). Unit Root Tests in Panel Data: Asymptotic and Finite-Sample Properties. Journal of Econometrics, 108, 1-24.

https://doi.org/10.1016/S0304-4076(01)00098-7

Li, C., \& Tanna, S. (2019). The Impact of Foreign Direct Investment on Productivity: New Evidence for Developing Countries. Economic Modelling, 80, 453-466.

https://doi.org/10.1016/j.econmod.2018.11.028

Lleshaj, L., \& Malaj, A. (2016). The Impact of Foreign Direct Investments (FDIs) on Economic Growth: The Solow Model in the Case of Albania. European Journal of Economics and Business Studies, 2, 152-163. https://doi.org/10.26417/ejes.v4i1.p152-162

Lucas, R. E. (1988). On the Mechanics of Economic Development. Journal of Monetary Economics, 22, 3-42. https://doi.org/10.1016/0304-3932(88)90168-7

Lucas, R. E. (1990). Why Doesn't Capital Flow from Rich to Poor Countries? American Economic Review, 80, 92-96.

Lumengo, B., \& Maphelane, P. (2017). Assessing the Relationship between Total Factor Productivity and Foreign Direct Investment in an Economy with a Skills Shortage: The Case of South Africa (pp. 1-14). Munich Personal RePEc Archive, Paper No. 83288.

Makki, S., \& Somwaru, A. (2004). Impact of Foreign Direct Investment and Trade on Economic Growth: Evidence from Developing Countries. American Journal of Agricultural Economics, 86, 795-801. https://doi.org/10.1111/j.0002-9092.2004.00627.x

Mankiw, N. G., Romer, D., \& Weil, D. N. (1992). A Contribution to the Empirics of Economic Growth. Quarterly Journal of Economics, 107, 407-437. https://doi.org/10.2307/2118477

Mboko, I. S. B. (2018). Efficacité interne du système d'enseignement secondaire au Congo (Internal Efficiency of the Secondary Education System in Congo). PhD Thesis, Brazzaville: Faculty of Economic Sciences, Marien Ngouabi University.

Miyamoto, C. (2003). Human Capital Formation and Foreign Direct Investment in Developing Countries. Working Paper No. 211, Paris: OECD Development Centre.

Nelson, R., \& Phelps, E. (1966). Investment in Humans. Technological Diffusion and Economic Growth. American Economic Review, 61, 69-75.

Romer, P. (1986). Increasing Return and Long-Run Growth. Journal of Political Econo$m y$, 94, 1002-1037. https://doi.org/10.1086/261420

Romer, P. (1987). Growth Based on Increasing Returns due to Specialization. American Economic Review, 77, 56-62.

Romer, P. (1990). Endogenous Technological Change. Journal of Political Economy, 98, 71-102.

Roodman, D. (2009). How to Doxtabond2: An Introduction to Difference and System GMM in Stata. The Stata Journal, 9, 86-136. https://doi.org/10.1177/1536867X0900900106

Solow, R. M. (1956). A Contribution to the Theory of Economic Growth. Quarterly Journal of Economics, 70, 65-94. https://doi.org/10.2307/1884513

Solow, R. M. (1957). Technical Change and the Aggregate Production Function. The Review of Economics and Statistics, 39, 312-320. https://doi.org/10.2307/1926047

Swan, T. W. (1956). Economic Growth and Capital Accumulation. Economic Record, 32, 334-361. https://doi.org/10.1111/j.1475-4932.1956.tb00434.x

Wang, Q. (2015). Fixed-Effect Panel Threshold Model Using Stata. The Stata Journal, 15, 
121-134. https://doi.org/10.1177/1536867X1501500108

World Bank (2019). World Development Indicators. https://datacatalog.worldbank.org/dataset/world-development-indicators

Xu, B. (2000). Multinational Enterprises, Technology Diffusion and Host Country Productivity Growth. Journal of Development Economics, 62, 477-493.

https://doi.org/10.1016/S0304-3878(00)00093-6 


\section{Appendix 1: Central Tendency Statistics}

\begin{tabular}{ccccccc}
\hline \multirow{2}{*}{ PAYS } & $\begin{array}{c}\text { GDP per capita 2010 } \\
\text { constant price in USD }\end{array}$ & FDI (in millions of USD) & \multicolumn{2}{c}{$\begin{array}{c}\text { Average number of } \\
\text { years of study }\end{array}$} \\
\cline { 2 - 7 } & $\begin{array}{c}\text { Annual } \\
\text { average }\end{array}$ & $\begin{array}{c}\text { Variation } \\
(\%)\end{array}$ & $\begin{array}{c}\text { Annual } \\
\text { average }\end{array}$ & $\begin{array}{c}\text { Variation } \\
(\%)\end{array}$ & $\begin{array}{c}\text { Annual } \\
\text { average }\end{array}$ & $\begin{array}{c}\text { Variation } \\
(\%)\end{array}$ \\
\hline Cameroon & 1294.9 & 1.19 & 169.5 & -1369.6 & 1.6 & 0.96 \\
CAR & 470.6 & -0.96 & 12.6 & -56.6 & 1.3 & 0.77 \\
Tchad & 619.0 & 0.92 & 113.3 & -304.4 & 1.6 & 1.26 \\
Congo & 2484.4 & 1.17 & 415.8 & 191.0 & 1.7 & 1.20 \\
Gabon & 10780.6 & 1.05 & 197.7 & -50.0 & 1.9 & 1.91 \\
CEMAC & 3129.9 & 0.67 & 181.8 & -317.9 & 1.6 & 1.2 \\
\hline
\end{tabular}

\section{Appendix 2: Result of the Estimation of the First Effect Model $^{7}$}

Research of the human capital threshold effect/change variable $=$ FDI

1) Threshold estimator (level = 95):

\begin{tabular}{cccc}
\hline Model & Threshold & lower & Upper \\
\hline Th-1 & 1.4255 & 1.4189 & 1.4257 \\
Th-21 & 1.5501 & 1.5467 & 1.5510 \\
Th-22 & 1.1954 & 1.1928 & 1.2013 \\
Th-3 & 1.0966 & 1.0924 & 1.1007 \\
\hline
\end{tabular}

2) Threshold effect test (bootstrap $=0300300$ ):

\begin{tabular}{cccccccc}
\hline Threshold & RSS & MSE & Fstat & Prob & Crit10 & Crit5 & Crit1 \\
\hline Single & $\cdot$ &. &. &. &. &. &. \\
Double & 0.9548 & 0.0049 & 3.18 & 0.7567 & 10.0186 & 11.0345 & 14.4472 \\
Triple & 0.9458 & 0.0048 & 1.85 & 0.9300 & 14.7710 & 22.3070 & 26.7448 \\
\hline
\end{tabular}

${ }^{7}$ Based on the threshold effect model of Hansen (1999), the implementation of the threshold effect model used in this article derives from Wang (2015). 
3) Fixed-effects (within) regression

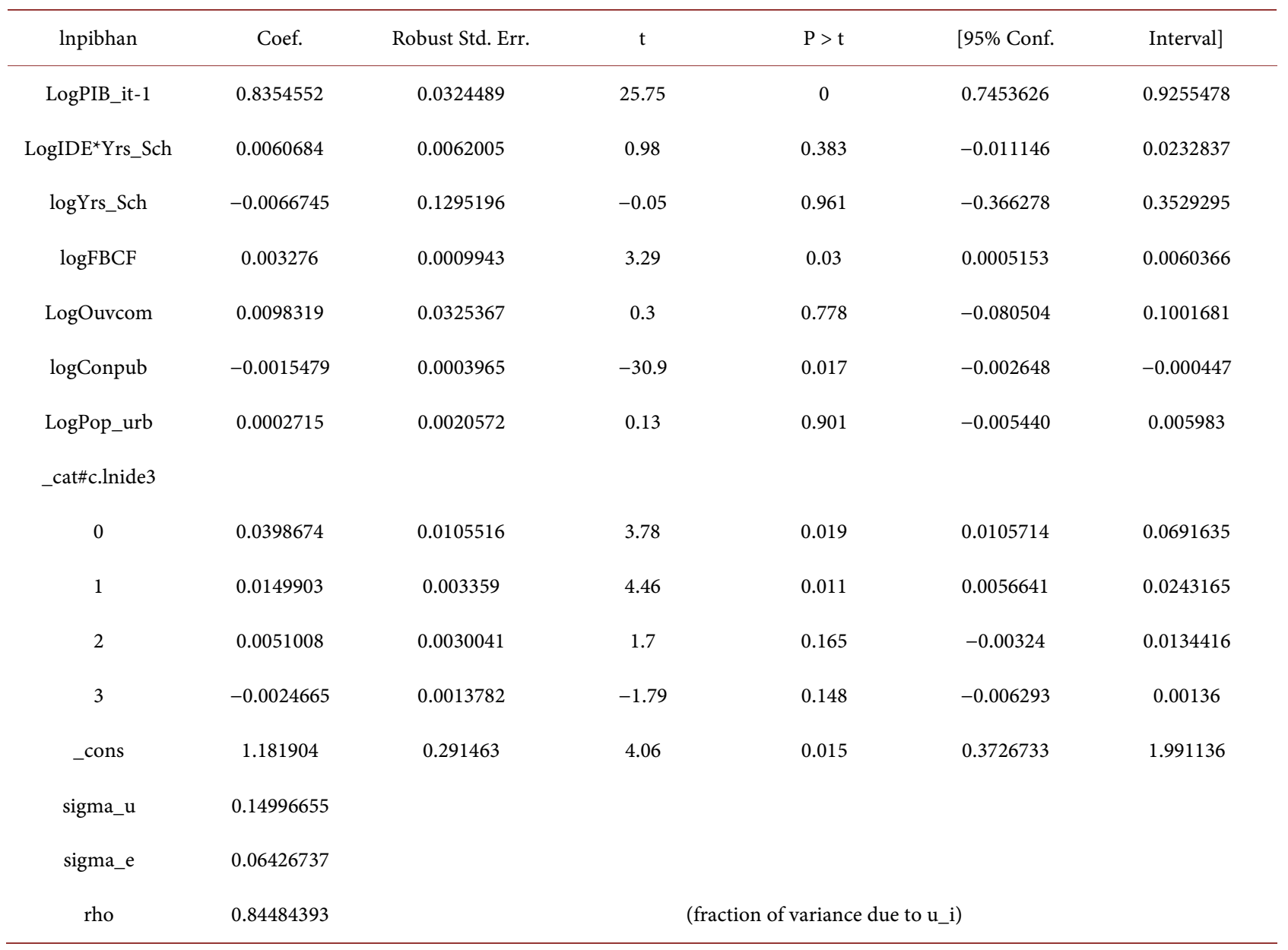

\section{Appendix 3: Result of the Estimation of the Second} Threshold Effect Model ${ }^{8}$

Research of the threshold effect of FDI/Regime change variable = human capital

1) Threshold estimator (level $=95$ )

\begin{tabular}{cccc}
\hline Modelé 1 & Threshold & Lower & Upper \\
\hline Th-1 & 1136.41 & 1135.55 & 1142.67 \\
\hline
\end{tabular}

2) Threshold effect test (bootstrap $=300$ )

\begin{tabular}{lccccccc}
\hline Threshold & RSS & MSE & Fstat & Prob & Crit10 & Crit5 & Crit1 \\
\hline Single & 1.0588 & 0.0054 & 2.06 & 0.8767 & 6.4139 & 7.1034 & 9.078 \\
\hline
\end{tabular}

${ }^{8}$ Based on the threshold effect model of Hansen (1999), the implementation of the threshold effect model used in this article derives from Wang (2015). 
3) Fixed-effects (within) regression

\begin{tabular}{|c|c|c|c|c|c|c|}
\hline lnpibhan & Coef. & Robust Std. Err. & $\mathrm{t}$ & $P>t$ & [95\% Conf. & Interval] \\
\hline LogPIB_it-1 & 0.8388 & 0.0402 & 20.8800 & 0.0000 & 0.7272 & 0.9503 \\
\hline LogIDE*Yrs_Sch & -0.0185 & 0.0074 & -2.5100 & 0.0660 & -0.0390 & 0.0020 \\
\hline IDE & 0.0001 & 0.0000 & 0.4900 & 0.6500 & 0.0000 & 0.0000 \\
\hline LogYrs_sch & 0.0989 & 0.3530 & 0.2800 & 0.7930 & -0.8812 & 1.0791 \\
\hline $\operatorname{logFBCF}$ & 0.0545 & 0.0303 & 1.8000 & 0.1470 & -0.0297 & 0.1388 \\
\hline LogOuvcom & 0.0218 & 0.0396 & 0.5500 & 0.6110 & -0.0882 & 0.1317 \\
\hline logConpub & -0.0841 & 0.0462 & -1.8200 & 0.1430 & -0.2125 & 0.0442 \\
\hline LogPop_urb & 0.0343 & 0.0798 & 0.4300 & 0.6900 & -0.1872 & 0.2557 \\
\hline _cat\#c.lnide3 & & & & & & \\
\hline 0 & -0.0525 & 0.1828 & -0.2900 & 0.7880 & -0.5599 & 0.4549 \\
\hline 1 & -0.0373 & 0.1757 & -0.2100 & 0.8420 & -0.5251 & 0.4506 \\
\hline _cons & 1.2545 & 0.5118 & 2.4500 & 0.0700 & -0.1666 & 2.6755 \\
\hline sigma_u & 0.15691467 & & & & & \\
\hline sigma_e & 0.0678491 & & & & & \\
\hline rho & 0.84248458 & \multicolumn{5}{|c|}{ (fraction of variance due to $u \_i$ ) } \\
\hline
\end{tabular}

